\title{
IRF5 is increased in labouring myometrium and regulates pro-labour mediators
}

\author{
Ratana Lim¹,2, Gillian Barker ${ }^{1,2}$ and Martha Lappas ${ }^{1,2}$ \\ ${ }^{1}$ Obstetrics, Nutrition and Endocrinology Group, Department of Obstetrics and Gynaecology, University of \\ Melbourne, Melbourne, Victoria, Australia and ${ }^{2}$ Mercy Perinatal Research Centre, Mercy Hospital for Women, \\ Heidelberg, Victoria, Australia
}

Correspondence should be addressed to M Lappas; Email: mlappas@unimelb.edu.au

\begin{abstract}
Preterm birth continues to be the leading cause of neonatal mortality and morbidities that can extend into adult life. Few treatment options stem from our incomplete understanding of the mechanisms of human labour and delivery. Activation of the inflammatory response in gestational tissues by inflammation and/or infection leads to the production of pro-inflammatory and pro-labour mediators, thus preterm birth. Interferon regulatory factor 5 (IRF5) has recently emerged as an important pro-inflammatory transcription factor involved in acute and chronic inflammation. The aims of this study were to determine the expression of IRF5 in human myometrium from labouring and non-labouring women, and whether IRF5 is involved in the genesis of pro-inflammatory and pro-labour mediators induced by pro-inflammatory cytokines or toll-like receptor (TLR) ligands. IRF5 mRNA and protein expression was significantly higher in human myometrium after spontaneous term labour, compared to non-labouring tissues. IRF5 mRNA expression was also significantly higher in primary myometrial cells treated with the pro-inflammatory cytokines IL1B or TNF. In primary myometrial cells, IRF5 knockdown by siRNA (silRF5) was associated with significantly decreased expression and or secretion of pro-inflammatory cytokines (IL1A, IL6), chemokines (CXCL8, CCL2), adhesion molecules (ICAM1, VCAM1) and contractionassociated proteins PTGS2, PGF $2 \alpha$ and PTGFR when in the presence of IL1B, TNF, fsI-1 (TLR2/6 ligand) or flagellin (TLR5 ligand). silRF5-transfected cells also displayed decreased NF-кB RELA transcriptional activity in the presence of these preterm birth mediators. Our study suggests a novel role for IRF5 in the regulation of the inflammatory response in human myometrium.

Reproduction (2018) 156 207-218
\end{abstract}

\section{Introduction}

Preterm birth continues to be a major obstetric healthcare situation (Liu et al. 2012), despite decades of research (Rubens et al. 2014). Of the 15 million babies born premature each year worldwide, over 1 million will die (Beck et al. 2010) and a significant proportion will experience health issues that extend into adult life (Saigal \& Doyle 2008, Mwaniki et al. 2012). Specifically, of 22,161 neonates born preterm, onethird had an impairment, such as learning difficulties or developmental delay $(59 \%)$, cerebral palsy $(21 \%)$ and hearing impairment (20\%) (Mwaniki et al. 2012). In Sweden, the prevalence of cerebral palsy in neonates born less than 28 weeks was 85.5 per 1000, but only 1.3 per 1000 for those born at least 37 weeks. The human and financial burden of preterm birth on the family and healthcare system is enormous (Petrou et al. 2011), costing the USA $\$ 26.2$ billion in 2005 alone. While up to one third of preterm births are indicated due to maternal or foetal reasons (Goldenberg et al. 2008), the remaining are due to spontaneous preterm births. Of all spontaneous preterm births, approximately $45 \%$ are due to preterm labour (Goldenberg et al. 2008), i.e. myometrial contractions with intact membranes. There are no treatments that can stop these contractions; tocolytics today alone do not extend the pregnancy beyond $48 \mathrm{~h}$, have not reduced the incidence of preterm birth, nor improved long-term outcomes for the preterm baby (Mitchell et al. 2013, Illanes et al. 2014, van Vliet et al. 2014). Tocolytics can only be improved by understanding the physiology of labour and the pathological processes involved in preterm labour; the myometrium, responsible for these uterine contractions, is thus an important area of study.

It is known that inflammation is central to preterm labour and can be induced by sterile inflammatory insults or from infection (Romero et al. 2006, Christiaens et al. 2008). Subsequent activation of the maternal immune system (Yuan et al. 2009) can ultimately lead to cervical ripening, foetal membrane rupture and myometrial contractions, thus spontaneous preterm birth. It has been shown that pro-inflammatory cytokines, chemokines and the cell adhesion molecule ICAM1 play important roles in these labour processes (Christiaens et al. 2008, Nadeau-Vallee et al. 2016, Sivarajasingam et al. 2016). 
Many pro-inflammatory cytokines and chemokines have been implicated in the inflammatory process of labour, including IL6, CXCL8 and CCL2. IL6 upregulates the expression of oxytocin receptors on myometrial cells, increasing their responsiveness to oxytocin stimulation and thus initiating contractions (Rauk et al. 2001). CXCL8 is a potent chemokine for neutrophils while CCL2 exhibits a chemotactic activity for monocytes and basophils. In myometrium, these cytokines and chemokines are consistently and markedly upregulated in preterm and term labour (Mittal et al. 2010, Shynlova et al. 2013, Sivarajasingam et al. 2016) and by stretch (Shynlova et al. 2013). Additionally, prostaglandin synthase 2 (PTGS2)-dependent prostaglandin $\mathrm{PGF}_{2 \alpha}$ is an important regulator of myometrial contractility (Olson 2003). Importantly, many of these pro-inflammatory and labour-associated genes are regulated by nuclear factorkappa B (NF-кB) (Barton \& Medzhitov 2003, Lindstrom \& Bennett 2005, Lappas \& Rice 2007). In human gestational tissue, NF-кB is activated by a broad range of stimuli including the pro-inflammatory cytokines TNF (Lim et al. 2017b) and IL1B (Lappas 2017b), and tolllike receptor (TLR) ligands such as the bacterial products fibroblast-stimulating lipopeptide (fsl-1) and flagellin (Lim et al. 2014, 2017a).

The interferon (IFN) regulatory factor (IRF) family are a group of nine transcription factors (IRF1-9). They are critical for regulating immune and inflammatory responses, and as such, defects in IRF expression and/or function are linked to numerous metabolic, cardiovascular and neurological diseases (Honda \& Taniguchi 2006, Zhao et al. 2015). We have previously shown that IRF1 is increased in term labour in foetal membranes and myometrium where it is involved in the genesis of IL1B- and TLR-induced pro-inflammatory cytokines, chemokines and contraction-associated proteins (Lim et al. 2016b). Numerous lines of evidence have now identified an important role for IRF5 in driving the inflammatory response. In vitro gene knockout or overexpression studies have demonstrated an essential role of IRF5 in the production of pro-inflammatory cytokines in response to numerous pathogens and TLR ligands (Takaoka et al. 2005, Krausgruber et al. 2010, Hedl \& Abraham 2012, 2011, Ren et al. 2014). In keeping with this, IRF5-knockout mice are resistant to lethal shock induced by TLR ligands (Takaoka et al. 2005), accumulate fewer neutrophils at the site of inflammation due to the reduced levels of chemokines (Xu et al. 2012, Weiss et al. 2015) and show reductions in serum and or tissue levels of inflammatory cytokines (Paun et al. 2008, Feng et al. 2012, Duffau et al. 2015, Oriss et al. 2017). Moreover, myeloid deficiency of IRF5 protects mice from liver fibrosis and alters hepatic macrophage transcriptome response to experimental fibrosis (Alzaid et al. 2016) while cells derived from IRF5-knockout mice produce lower levels of proinflammatory cytokines and or chemokines in response to TLR ligands (Tada et al. 2011, Duffau et al. 2015, Weiss et al. 2015). Notably, ChIP seq studies have shown that IRF5 regulates many inflammatory genes in cooperation with the RELA subunit of NF-kB (Saliba et al. 2014) while IRF5 knockdown suppresses RELA activation in human monocyte-derived cells (Hedl \& Abraham 2012). Finally, IRF5 gene polymorphisms are associated with a number of inflammatory diseases including rheumatoid arthritis (Lee et al. 2013), systemic lupus erythematosus (Salloum \& Niewold 2011), inflammatory bowel disease (Gathungu et al. 2012), pulmonary fibrosis (Zhao et al. 2017) and asthma (Wang et al. 2012).

The role of IRF5 in regulating inflammation associated with labour is not known. Thus, the aims of this present study were to characterise the expression of IRF5 in myometrium from non-labouring and labouring women and to determine if IRF5 is involved in the genesis of pro-inflammatory and pro-labour mediators induced by pro-inflammatory cytokines or TLR ligands. The proinflammatory cytokines IL1B and TNF, the TLR2/6 ligand fsl-1 and the TLR5 ligand flagellin were used to mimic inflammation associated with preterm labour (Lim et al. 2014, 2017a,b, Lappas 2017b).

\section{Materials and methods}

\section{Tissue collection}

Human myometrium was obtained (with Institutional Research and Ethics Committee approval) from the upper margin of the lower uterine segment incision during Caesarean section. Myometrium was brought to the research laboratory and processed within $15 \mathrm{~min}$ of delivery. Myometrial tissues were washed in PBS to remove excess blood, cleared of serosa, fibrous or damaged tissue and visible blood vessels, and then dissected into smaller pieces. Tissues were immediately snapfrozen in liquid nitrogen and stored at $-80^{\circ} \mathrm{C}$ for expression studies or used immediately for cell culture experiments.

For all studies, tissue samples were obtained from women who delivered healthy, singleton infants. Women with any underlying medical conditions such as diabetes, asthma, polycystic ovary syndrome, preeclampsia and macrovascular complications were excluded. Additionally, women with multiple pregnancies, obese women and foetuses with chromosomal abnormalities were excluded.

For the expression studies, myometrial biopsies were collected from women at term Caesarean section from in the absence of labour or during active spontaneous term labour ( $n=9$ patients per group). Indications for Caesarean section in the absence of labour were breech presentation and/or previous Caesarean section. Indications for Caesarean section in the labouring samples were for foetal malpresentation, foetal distress and delayed or failure to progress. Labour was defined as the presence of regular uterine contractions (every 3-4 min) resulting in cervical effacement and dilation. None of the patients received any medications to augment or induce labour. Relevant clinical details for the patients are detailed in Table 1. 
Table 1 Clinical characteristics of patients.

\begin{tabular}{lcc}
\hline & $\begin{array}{c}\text { No labour }(n=9 \\
\text { patients) }\end{array}$ & $\begin{array}{c}\text { In labour }(n=9 \\
\text { patients) }\end{array}$ \\
\hline Maternal age (years) & $31(1.6)$ & $31(1.5)$ \\
Pre-pregnancy maternal BMI & $22.4(1.1)$ & $22.6(0.9)$ \\
Gravida & $2.1(0.3)$ & $2.0(0.4)$ \\
Parity & $1.0(0.3)$ & $0.6(0.3)$ \\
Gestational age (weeks) & $38.9(0.3)$ & $39.4(0.5)$ \\
Foetal gender & 2 female; 7 male & 4 female; 5 male \\
Birthweight (g) & $3562(161)$ & $3542(84)$ \\
Labour & & \\
$\quad$ No labour (\%) & 100 & 0 \\
$\quad$ Spontaneous (\%) & 0 & 100 \\
$\quad$ Duration of labour (min) & $\mathrm{N} / \mathrm{A}$ & $642(89)$ \\
Membrane rupture & & \\
$\quad$ SROM (\%) & 0 & 22 \\
PROM (\%) & 0 & 56 \\
ARM (\%) & 100 & 56 \\
\hline
\end{tabular}

Values represent mean ( \pm S.E.M.) unless otherwise specified.

For the cell culture studies, fresh myometrium was obtained from women who delivered healthy, singleton infants at term (37-40 weeks gestation) undergoing elective Caesarean section in the absence of labour. Myometrial cells were isolated and cultured as previously described (Lim et al. 2013a).

\section{IRF5 siRNA transfection in primary myometrial cells}

To determine the effect of pro-inflammatory mediators on IRF5 expression, myometrial cells at approximately $80 \%$ confluence were incubated in the absence or presence of $1 \mathrm{ng} / \mathrm{mL}$ IL1B (PeproTech; Rocky Hill, NJ, USA), $10 \mathrm{ng} / \mathrm{mL}$ TNF (PeproTech), 250 ng/mL fsl-1 (InVivoGen; San Diego, CA, USA) or $1 \mu \mathrm{g} / \mathrm{mL}$ flagellin (purified flagellin from Salmonella typhimurium; InVivoGen) for $20 \mathrm{~h}$. Cells were collected and stored at $-80^{\circ} \mathrm{C}$ until assayed for IRF5 mRNA expression by qRT-PCR as detailed below. Experiments were performed from myometrium obtained from five patients.

To determine if IRF5 regulates pro-labour mediators, transfection of primary myometrial cells with siRNA was performed as previously described (Lim et al. 2015). Briefly, myometrial cells at approximately 50\% confluence were transfected using Lipofectamine 3000 according to manufacturer's guidelines (Life Technologies). IRF5 siRNA (silRF5) and negative control siRNA (siCONT) were obtained from Ambion (Thermo Fisher Scientific). Cells were transfected with $50 \mathrm{nM}$ silRF5 or $50 \mathrm{nM}$ siCONT in DMEM/F-12 for $48 \mathrm{~h}$. The medium was then replaced with DMEM/F-12 (containing $0.5 \%$ BSA) with or without $1 \mathrm{ng} /$ $\mathrm{mL}$ IL1B, $10 \mathrm{ng} / \mathrm{mL}$ TNF, $250 \mathrm{ng} / \mathrm{mL}$ fs -1 or $1 \mu \mathrm{g} / \mathrm{mL}$ flagellin and the cells were incubated at $37^{\circ} \mathrm{C}$ for an additional $20 \mathrm{~h}$. After final incubation, cells and conditioned media were collected separately. The cells were used immediately for cell adhesion and cell contraction assays or stored at $-80^{\circ} \mathrm{C}$ for RNA extraction. The conditioned media was stored at $-80^{\circ} \mathrm{C}$ for analysis of endpoints by ELISA. Data are presented as fold change relative to IL1B, TNF-, fs $1-1$ - or flagellin-stimulated cells. Experiments were performed from myometrium obtained from seven patients.

\section{RELA luciferase assay}

To determine the effect of silRF5 on RELA transcriptional activity, a luciferase assay was performed as previously described (Lim et al. 2016b). Briefly, primary myometrial cells were transfected with $300 \mathrm{ng} / \mathrm{mL}$ RELA reporter construct (Qiagen) using FuGENE HD transfection reagent (Promega). After $6 \mathrm{~h}$, cells were transfected with $50 \mathrm{nM}$ of silRF5 or siCONT (as detailed above) for $48 \mathrm{~h}$. The medium was then replaced with DMEM/F-12 (containing $0.5 \%$ BSA), with or without $1 \mathrm{ng} / \mathrm{mL}$ IL1B, $10 \mathrm{ng} / \mathrm{mL}$ TNF, $250 \mathrm{ng} / \mathrm{mL}$ fsl- 1 or $1 \mu \mathrm{g} /$ $\mathrm{mL}$ flagellin and the cells incubated at $37^{\circ} \mathrm{C}$ for an additional $20 \mathrm{~h}$. After final incubation, cells were harvested in lysis buffer, and luminescence activity was measured using a luciferase reporter assay kit (Life Research; Scoresby, Vic, Australia) and Renilla luciferase flash assay kit (Thermo Fisher Scientific) as instructed. The ratio of the firefly luciferase level to the Renilla luciferase level was determined, and the results are expressed as a ratio of normalised luciferase activity. The experiments were performed from myometrium obtained from six patients.

\section{Mice studies}

Animal studies were conducted with approval from the Austin Health's Animal Ethics Committee. Eight-week-old timed pregnant $\mathrm{C} 57 \mathrm{BL} / 6$ female mice were purchased from WEHI (Melbourne, Australia). Timed pregnancies were achieved by housing female mice with male mice overnight and mice found to have vaginal plugs the next morning were considered to be 0.5 day post-coitum (dpc). Studies were performed as previously described (Lappas 2018). For LPS-induced preterm labour, $15.5 \mathrm{dpc}$ timed pregnant C57BL/6 female mice were intraperitoneally injected with LPS (serotype O26:B6; $15 \mu \mathrm{g}$ in $50 \mu \mathrm{L}$ of PBS; Sigma) or sterile PBS (vehicle control). This model of preterm labour results in a high rate of preterm delivery (18$22 \mathrm{~h}$ post LPS treatment) and does not cause maternal mortality. None of the vehicle-injected mice went into labour. The mice were killed on the birth of one pup, and time-matched controls were killed directly afterward. Myometrial tissue was washed in PBS, flash frozen and stored at $-80^{\circ} \mathrm{C}$ until further analysis by qRT-PCR as detailed below.

\section{Immunohistochemistry}

Immunohistochemistry (IHC) was performed on paraffin sections as described previously (Lim et al. 2015) using the IHC Select HRP Detection Set (Merck Millipore). Briefly, sections were deparaffinised followed by an antigen retrieval step (boiled in $10 \mathrm{mM}$ Tris, $1 \mathrm{mM}$ EDTA, pH 9.0 for $10 \mathrm{~min}$ followed by 20 -min incubation) and then endogenous peroxidases were inactivated by adding $3 \%$ hydrogen peroxide for $10 \mathrm{~min}$. After blocking (blocking reagent: normal goat serum in PBS) for $5 \mathrm{~min}$, sections were incubated with $2 \mu \mathrm{g} / \mathrm{mL}$ rabbit polyclonal anti-IRF5 (catalogue number GTX113477, GeneTex; Irvine, CA, USA) in 1\% (wt/vol) bovine serum albumin in PBS and incubated in a humidity chamber at $4{ }^{\circ} \mathrm{C}$ overnight. Binding sites were labelled with biotin-conjugated rabbit anti-goat IgG antibody followed by the streptavidin-HRP. Haematoxylin was used for nuclear staining. Negative control slides, where 
primary antibody was replaced with rabbit $\lg$, were also performed. Positive controls, which were composite slides with tonsil, breast tumour and ovarian tumour, were included in each run.

\section{$R N A$ extraction and $q R T-P C R$}

RNA extractions and qRT-PCR was performed as previously described (Lim et al. 2015). RNA concentration and purity were measured using a NanoDrop ND1000 (Thermo Fisher Scientific). RNA was converted to cDNA using the highcapacity cDNA reverse transcription kit (Thermo Fisher Scientific) according to the manufacturer's instructions. The RT-PCR was performed using the CFX384 Real-Time PCR detection system (Bio-Rad Laboratories) using $100 \mathrm{nM}$ of pre-designed and validated QuantiTect primers (primer sequences not available) (Qiagen). For the human samples, gene $\mathrm{Ct}$ values were normalised to the average YWHAZ and succinate dehydrogenase (SDHA) Ct values of the same cDNA sample. For the mouse samples, gene $\mathrm{Ct}$ values were normalised to the average actin and GAPDH Ct values of the same cDNA sample. Fold differences were determined using the comparative Ct method.

\section{Western blotting}

Western blotting was performed as previously described (Lim et al. 2015). Blots were incubated in a $1 \mu \mathrm{g} / \mathrm{mL}$ rabbit polyclonal anti-IRF5 (catalogue number GTX113477, GeneTex; Irvine, CA, USA) prepared in blocking buffer (5\% skim milk in TBS (50 mM Tris- $\mathrm{HCl}, \mathrm{pH} 7.5,150 \mathrm{mM} \mathrm{NaCl}$ ) with $0.05 \%$ Tween-20) for $16 \mathrm{~h}$ at $4{ }^{\circ} \mathrm{C}$. Semi-quantitative analysis of the relative density of the bands in Western blots was performed using Quantity One 4.2.1 image analysis software (Bio-Rad Laboratories). Protein normalisation was performed as previously described (Lim et al. 2016b). For the expression studies, the level of IRF5 was normalised to Ponceau S stain; a section of the Ponceau S-stained membrane was chosen, which did not show variation with labor status.

\section{Enzyme immunoassays}

Assessment of cytokine and chemokine release of IL6 and CXCL8 was performed using the CytoSet sandwich ELISA according to the manufacturer's instructions (LifeTechnologies). The release of CCL2, sICAM1 and sVCAM1 was performed by sandwich ELISA from R\&D Systems (Minneapolis, MN, USA) according to the manufacturer's instructions. The release of PGF $_{2 \alpha}$ into the incubation medium was assayed using a commercially available competitive enzyme immunoassay kit according to the manufacturer's specifications (Cayman Chemical Company). The interassay and intraassay coefficients of variation for all assays were less than $10 \%$.

\section{Statistical analysis}

All statistical analyses were undertaken using GraphPad Prism (GraphPad Software). For Figure 1 and Tables 1, 2, a paired or unpaired Student's t-test was used to assess the statistical significance between normally distributed data; otherwise, the nonparametric Mann-Whitney $U$ (unpaired) or the Wilcoxon (matched pairs) tests were used. For Figs 2, 3, 4, 5 and 6, the homogeneity of data was assessed by Bartlett's test, and when significant, data were logarithmically transformed before analysis by a repeated measures one-way ANOVA (with LSD
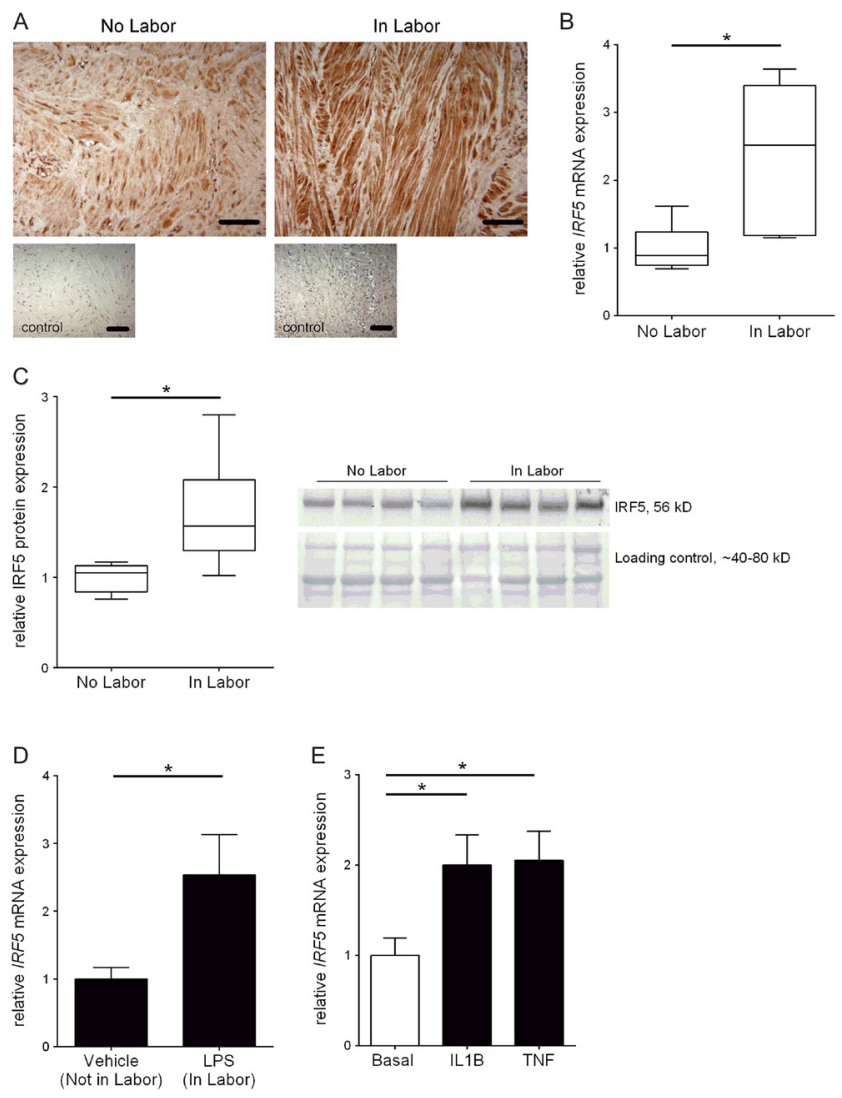

Figure 1 Expression of IRF5 in human myometrium. (A, B and C) Human myometrium was obtained at term Caesarean section from women at term in the absence of labour (term no labour, $n=8$ patients) or during labour at term (term in labour, $n=8$ patients). (A) Immunohistochemical expression of IRF5. These sections are representative of one patient sample per group. Negative control is also displayed. Original magnification $\times 100$. Scale bar $100 \mu \mathrm{m}$. (B) IRF5 mRNA abundance was analysed by qRT-PCR. Data are displayed as box-and-whisker plots (median, interquartile range). $* P \leq 0.05$, Mann-Whitney $U$ test. (C) IRF5 protein expression was analysed by Western blotting. Representative Western blot from four patients per group is shown. Data are displayed as box-and-whisker plots (median, interquartile range). ${ }^{*} P \leq 0.05$, Mann-Whitney $U$ test. (D) Mice were injected with a single i.p. injection of $15 \mu \mathrm{g}$ of LPS at 15.5 dpc. Mice were considered in labour on birth of one pup. LPS-treated mice were killed on the birth of one pup, and timematched vehicle-injected mice were killed directly afterward ( $n=4$ mice/group). IRF5 mRNA expression in myometrium was analysed by qRT-PCR and the fold change was calculated relative to vehicle group. All data are displayed as mean \pm S.E.M. ${ }^{*} P<0.05$, unpaired Students $t$-test. (E) Human myometrial cells were incubated in the absence or presence of $1 \mathrm{ng} / \mathrm{mL}$ IL1B or $10 \mathrm{ng} / \mathrm{mL}$ TNF for $20 \mathrm{~h}(n=6$ patients per treatment). IRF5 mRNA expression was analysed by qRT-PCR and the fold change was calculated relative to basal. Data are displayed as mean \pm S.E.M. ${ }^{*} P \leq 0.05$, paired Students $t$-test. 
post hoc testing to discriminate among the means). Statistical significance was ascribed to a $P$ value $\leq 0.05$. Data are expressed as mean \pm S.E.M.

\section{Results}

\section{IRF5 expression in human myometrium}

The localisation of IRF5 in human term myometrium was determined by immunohistochemistry. Within sections of myometrium, there was strong cytoplasmic and some nuclear IRF5 protein localised to longitudinal and transverse smooth muscle fibres. IRF5 staining was stronger in tissues obtained from labouring women compared to non-labouring women (Fig. 1A). Of note, there was no staining present in the negative controls. The mRNA and protein expression was also investigated in myometrium from non-labouring and labouring women at term. As depicted in Fig. 1B and C, IRF5 mRNA and protein expression was significantly higher in myometrium after spontaneous term labour when compared to non-labouring tissues.

To determine whether a comparable upregulation in IRF5 mRNA expression was associated with preterm labour, we utilised a mouse model of preterm labour. In this model, LPS was injected into $15.5 \mathrm{dpc}$ mice and mice were killed on the birth of one pup (between 18 and $22 \mathrm{~h}$ post LPS injection). A time-matched vehicleinjected mouse was killed directly afterward; none of the vehicle-injected mice delivered preterm. LPS significantly increased IRF5 mRNA expression in the mouse myometrium when compared with vehicleinjected controls (Fig. 1D).

We next sought to determine if the pro-inflammatory cytokines IL1B and TNF, which are increased in labouring myometrium (Young et al. 2002), may be causing the increase in IRF5. To do this, we treated primary cells isolated from human myometrium, in the absence or presence of IL1B or TNF for $20 \mathrm{~h}$. As shown in Fig. 1E, IL1B or TNF treatment induced a significant increase (2-fold increase) in IRF5 mRNA expression.

\section{IRF5 regulates cytokine- and TLR-induced pro- inflammatory cytokines in primary myometrial cells}

To determine if IRF5 regulates cytokine and TLR-induced pro-labour mediators, primary cells were isolated from human myometrium and IRF5 was knocked down by siRNA. The efficacy of silRF5 transfection was assessed by qRT-PCR; when compared to siCONT-transfected cells, there was a $77 \%$ decrease in IRF5 mRNA expression in silRF5-transfected cells $(1.00 \pm 0.22$ vs $0.23 \pm 0.05)$. There was no effect of silRF5 on cell viability as determined by MTT cell viability assay (data not shown).

Figure 2 depicts the effect of silRF5 on IL1A and IL6 mRNA expression and IL6 secretion. As expected, in cells transfected with siCONT, treatment with IL1B, TNF, fsl-1 and flagellin significantly increased IL1A and IL6 mRNA expression and release of IL6. In silRF5transfected cells, there was a significant decrease in ILIA and IL6 mRNA expression and IL6 release when stimulated with IL1B (Fig. 2A, B and C) and fsl-1 (Fig. 2G, $\mathrm{H}$ and I). While there was no effect of silRF5 on TNF and flagellin-stimulated IL $1 A$ mRNA expression (Fig. 2D and J), there was a significant decrease in IL6 mRNA expression and release when stimulated with TNF (Fig. 2E and F) and flagellin (Fig. $2 \mathrm{~K}$ and L). As shown in Table 2, there was no effect of silRF5 on IL1A and IL6 mRNA expression and IL6 secretion under basal conditions. As previously reported (Lim et al. 2016b), IL1A and IL1B levels are not detectable in the incubation media from human primary myometrial cells and thus not assessed.

\section{IRF5 regulates cytokine- and TLR-induced chemokines in primary myometrial cells}

The effect of silRF5 on chemokine expression of CXCL8 and CCL2 is depicted in Fig. 3. Expectedly, in cells transfected with siCONT, treatment with IL1B, TNF, fsl-1 and flagellin significantly increased CXCL8 and CCL2 mRNA expression and release. In silRF5-transfected cells, there was a significant decrease in IL1B-induced CXCL8 and CCL2 mRNA expression, but there was no effect on IL1B-induced CXCL8 and CCL2 release (Fig. 3A, B, C and D). There was a significant decrease in TNF-induced CCL2 mRNA expression, but no effect on TNF-induced CXCL8 mRNA expression and release, and release of $\mathrm{CCL} 2$ (Fig. 3E, F, G and $\mathrm{H}$ ). In silRF5transfected cells, there was a significant decrease in fsl-1- and flagellin-induced CXCL8 and CCL2 mRNA expression and release (Fig. 3I, J, K, L, M, N, O and $\mathrm{P})$. As shown in Table 2, there was no effect of silRF5 on CXCL8 and CCL2 mRNA expression and secretion under basal conditions.

Table 2 Effect of silRF5 on basal mRNA expression and secretion of pro-labour mediators in human primary myometrial cells.

\begin{tabular}{lcccccccccccccc}
\hline & $\begin{array}{c}\text { IL1A } \\
\text { mRNA } \\
\text { expression }\end{array}$ & $\begin{array}{l}\text { IL6 mRNA } \\
\text { expression }\end{array}$ & $\begin{array}{c}\text { IL6 } \\
\text { release } \\
(\mathrm{ng} / \mathrm{mL})\end{array}$ & $\begin{array}{c}\text { CXCL8 } \\
\text { mRNA } \\
\text { expression }\end{array}$ & $\begin{array}{c}\text { CXCL8 } \\
\text { release } \\
(\mathrm{ng} / \mathrm{mL})\end{array}$ & $\begin{array}{c}\text { CCL2 } \\
\text { mRNA } \\
\text { expression }\end{array}$ & $\begin{array}{c}\text { CCL2 } \\
\text { release } \\
(\mathrm{ng} / \mathrm{mL})\end{array}$ & $\begin{array}{c}\text { ICAM1 } \\
\text { mRNA } \\
\text { expression }\end{array}$ & $\begin{array}{c}\text { sICAM1 } \\
\text { release } \\
(\mathrm{ng} / \mathrm{mL})\end{array}$ & $\begin{array}{c}\text { VCAM1 } \\
\text { mRNA } \\
\text { expression }\end{array}$ & $\begin{array}{c}\text { sVCAM1 } \\
\text { release } \\
(\mathrm{ng} / \mathrm{mL})\end{array}$ \\
\hline siCONT & $0.04 \pm 0.02$ & $0.06 \pm 0.02$ & $1.26 \pm 0.61$ & $2.12 \pm 0.99$ & $3.46 \pm 0.92$ & $1.95 \pm 1.10$ & $1.75 \pm 0.70$ & $0.15 \pm 0.05$ & $0.34 \pm 0.11$ & $0.20 \pm 0.06$ & $0.31 \pm 0.17$ \\
silRF5 & $0.04 \pm 0.02$ & $0.06 \pm 0.03$ & $0.92 \pm 0.43$ & $1.93 \pm 0.98$ & $3.20 \pm 1.06$ & $1.50 \pm 0.86$ & $1.59 \pm 0.67$ & $0.16 \pm 0.06$ & $0.31 \pm 0.10$ & $0.18 \pm 0.06$ & $0.26 \pm 0.15$
\end{tabular}

Data displayed as mean \pm S.E.M. 

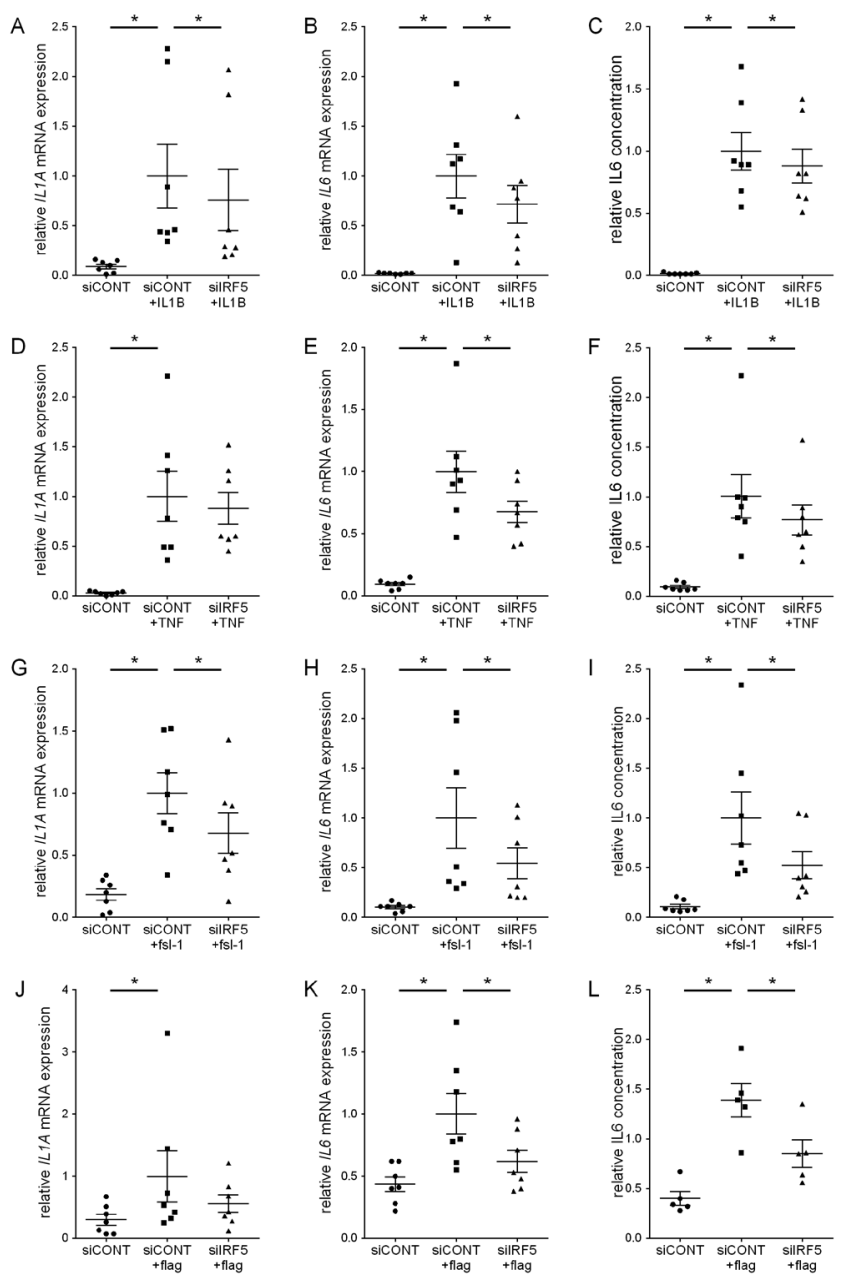

Figure 2 Effect of silRF5 on pro-inflammatory cytokines in primary myometrial cells. Human primary myometrial cells were transfected with $50 \mathrm{nM}$ siCONT or $50 \mathrm{nM}$ silRF5 for $48 \mathrm{~h}$ and then treated with (A, B and C) $1 \mathrm{ng} / \mathrm{mL} \mathrm{IL} 1 \mathrm{~B}$, (D, E and F) $10 \mathrm{ng} / \mathrm{mL}$ TNF, ( $\mathrm{H}$ and $\mathrm{I}$ ) $250 \mathrm{ng} / \mathrm{mL}$ fsl- 1 or (J, K and L) $1 \mu \mathrm{g} / \mathrm{mL}$ flagellin (flag) for an additional $20 \mathrm{~h}$ ( $n=5-7$ patients). (A, B, D, E, G, H, J and K) ILIA and IL6 mRNA expression was analysed by qRT-PCR. (C, F, I and L) The

concentration of IL6 in the incubation medium was assayed by ELISA. For all data, the fold change was calculated relative to IL1B-, TNF-, fsl-1 - or flag-treated cells. Individual data points represent 5-7 independent experiments and displayed as mean \pm S.E.M. ${ }^{*} P \leq 0.05$ (repeated-measures one-way ANOVA).

\section{IRF5 regulates cytokine- and TLR-induced adhesion molecules in primary myometrial cells}

The effect of silRF5 on the expression of adhesion molecules ICAM1 and VCAM1 is demonstrated in Fig. 4. Treatment of siCONT-transfected cells with IL1B, TNF, fs -1 and flagellin expectedly increased ICAM 1 and VCAM1 mRNA expression and release of sICAM1 and sVCAM1. In silRF5-transfected cells, there was no effect on ICAM1 mRNA expression when treated with IL1B, TNF, fsl-1 or flagellin (Fig. 4A, E, I and M). In contrast, there was a significant decrease in the release of sICAM1 in silRF5-transfected cells with stimulated with all treatments (Fig. 4B, F, J and N). In silRF5-transfected cells, there was a significant decrease in IL1B, TNF, fsl-1 and flagellin-induced VCAM1 mRNA expression and release (Fig. 4C, D, G, H, K, L, O and P). As shown in Table 2, there was no effect of silRF5 on ICAM1 and VCAM1 mRNA expression and sICAM1 and sVCAM1 secretion under basal conditions.

\section{IRF5 regulates IL1B-induced contraction-associated proteins in primary myometrial cells}

Primary myometrial cells treated with IL1B were used to determine the effect of silRF5 on the expression of mediators in the PTGS2-prostaglandin pathway. IL1B significantly increased PTGS2 and PTGFR mRNA expression and release of $\mathrm{PGF}_{2 \alpha}$ in myometrial cells transfected with siCONT (Fig. 5). The effect of silRF5 was a significant decrease in IL1B-induced PTCS2 and PTGFR mRNA expression and PGF $_{2 \alpha}$ secretion.

\section{IRF5 regulates NF-KB RELA transcriptional activity}

A luciferase assay was used to determine the effect of IRF5 silencing on NF-KB RELA transcriptional activity. In siCONT-transfected myometrial cells, treatment with IL1B, TNF, fsI-1 or flagellin significantly increased NF- $\mathrm{kB}$ RELA transcriptional activity (Fig. 6). In cells transfected with silRF5, there was a significant attenuation of NF- $\mathrm{kB}$ RELA transcriptional activity when stimulated with all treatments.

\section{Discussion}

The findings of this study demonstrate that IRF5 is increased in myometrium obtained from labouring women when compared to myometrium obtained from non-labouring women at term. Additionally, using a mouse model of preterm labour induced by LPS, we found that LPS significantly upregulated IRF5 mRNA expression in the maternal myometrium as compared with vehicle-injected controls. Functional studies in primary human myometrial cells demonstrated a pro-inflammatory and pro-labour role for IRF5. Specifically, silencing of IRF5 using siRNA showed a significant attenuation of cytokine- or TLR-induced proinflammatory cytokines (IL1A, IL6), chemokines (CCL2, CXCL1, CXCL8), adhesion molecules (ICAM1, VCAM1) and contraction-associated proteins (PTCS2, PTCFR, $\mathrm{PGF}_{2 \alpha}$ ). Additionally, NF-KB RELA transcriptional activity was significantly reduced in silRF5-transfected myometrial cells, suggesting that IRF5 may regulate pro-inflammatory and pro-labour mediators via NF- $\kappa$ B signalling.

Increased expression of IRF5 in labouring myometrium, which is characterised by increased inflammation (Bollapragada et al. 2009, Weiner et al. 2010), is in agreement with studies in non-gestational 

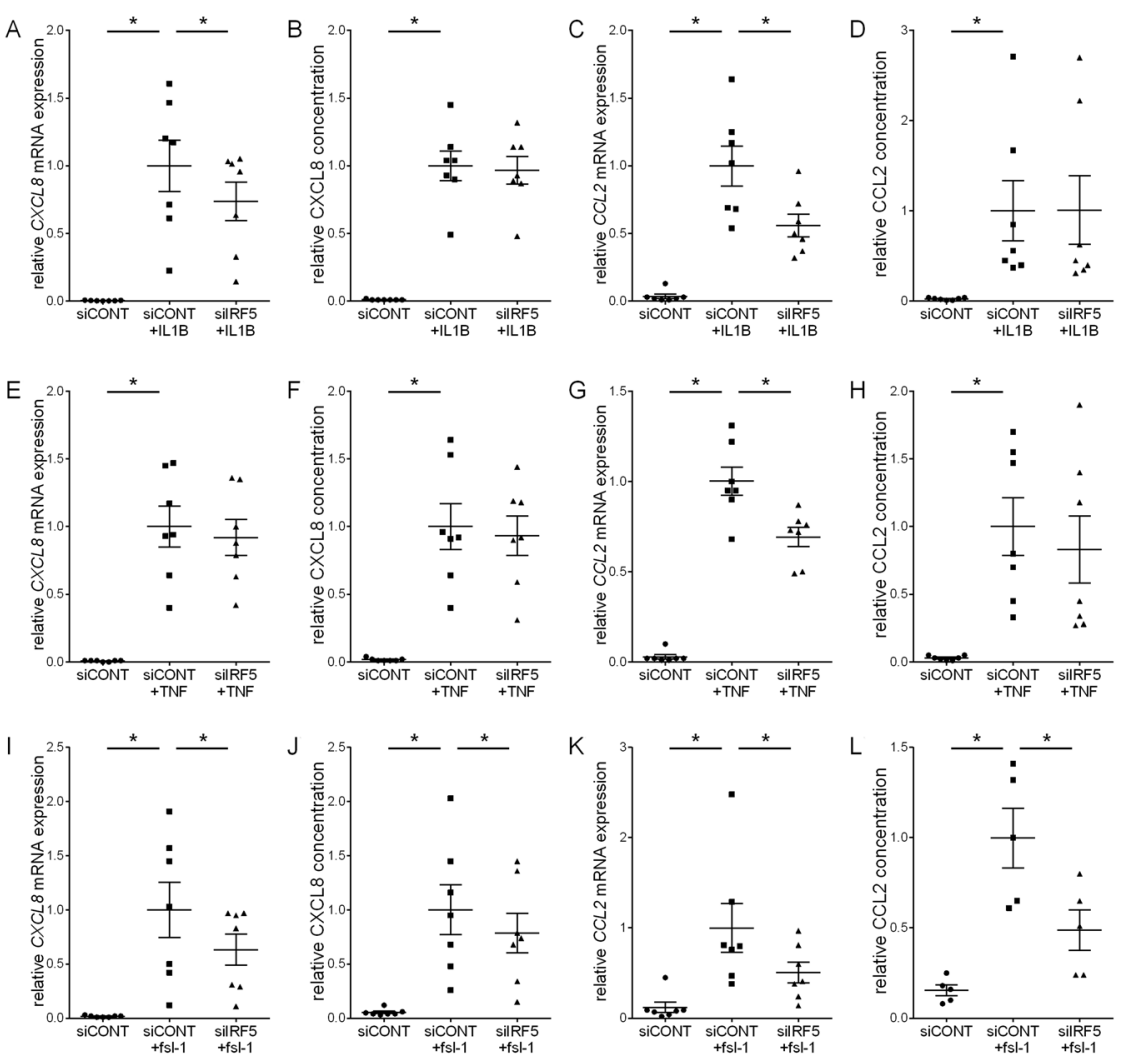

Figure 3 Effect of silRF5 on chemokines in primary myometrial cells. Human primary myometrial cells were transfected with $50 \mathrm{nM}$ siCONT or $50 \mathrm{nM}$ silRF5 for $48 \mathrm{~h}$ and then treated with (A, B, C and D) $1 \mathrm{ng} / \mathrm{mL}$ IL1B, (E, $\mathrm{F}, \mathrm{G}$ and $\mathrm{H}) 10 \mathrm{ng} / \mathrm{mL} T N F$, (I, J, K and L) $250 \mathrm{ng} / \mathrm{mL}$ fsl- 1 or (M, N, O and P) $1 \mu \mathrm{g} / \mathrm{mL}$ flagellin (flag) for an additional $20 \mathrm{~h}(n=5-7$ patients). (A, C, E, G, I, K, M, O) CXCL8 and CCL2 mRNA expression was analysed by qRT-PCR. (B, D, F, H, J, L, N, P) The concentration of CXCL8 and CCL2 in the incubation medium was assayed by ELISA. For all data, the fold change was calculated relative to IL1B-, TNF-, fsl-1- or flag-treated cells. Individual data points represent 5-7 independent experiments and displayed as mean \pm S.E.M. ${ }^{*} P \leq 0.05$ (repeated-measures one-way ANOVA).

tissues; higher IRF5 is observed in a number of diseases associated with inflammation including asthma (Oriss et al. 2017), arthritis (Weiss et al. 2013) and liver fibrosis (Alzaid et al. 2016). It is worth noting, that for the human samples, the majority of labouring cases were obtained from women who were delivered by Caesarean section for failure to progress in labour. Interestingly, a recent study showed that there is an exaggerated inflammatory response in myometrium obtained from labouring women who had a Caesarean delivery because they failed to progress in labour when compared to those who had a Caesarean delivery due to foetal distress or foetal malpresentation (Chaemsaithong et al. 2013). Thus, it is possible that the increase in IRF5 expression during labour may be due to dysfunctional myometrial signalling in the failure to progress group. However, our studies in mice, whereby IRF5 mRNA expression was increased in maternal myometrium during preterm labour, reassuringly suggests that IRF5 expression is increased by mechanisms associated with labour and

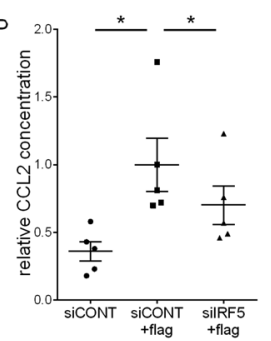

not because of dysfunctional myometrial signalling due to failure to progress group.

Whether increased IRF5 observed in labour in this study is a cause or consequence of labour is not known. It would therefore be of interest to determine if temporal changes occur in IRF5 expression in myometrium; however, obtaining myometrial biopsies from early/ mid pregnancy is extremely difficult. Regardless, the mechanisms leading to increased IRF5 expression in labouring myometrium are not known but most likely a consequence of the inflammatory response associated with labour. In non-gestational tissues, IRF5 expression is higher in leukocytes of inflammatory states (Swindell et al. 2010, Krausgruber et al. 2011, Wang et al. 2012, Weiss et al. 2013). Although recent studies suggest that leukocyte infiltration and/or activation are not a prerequisite for labour initiation (Singh et al. 2017), higher expression of leukocytes are observed in labouring myometrium (Osman et al. 2003). Thus, it is possible that the differences seen in labouring myometrium may 

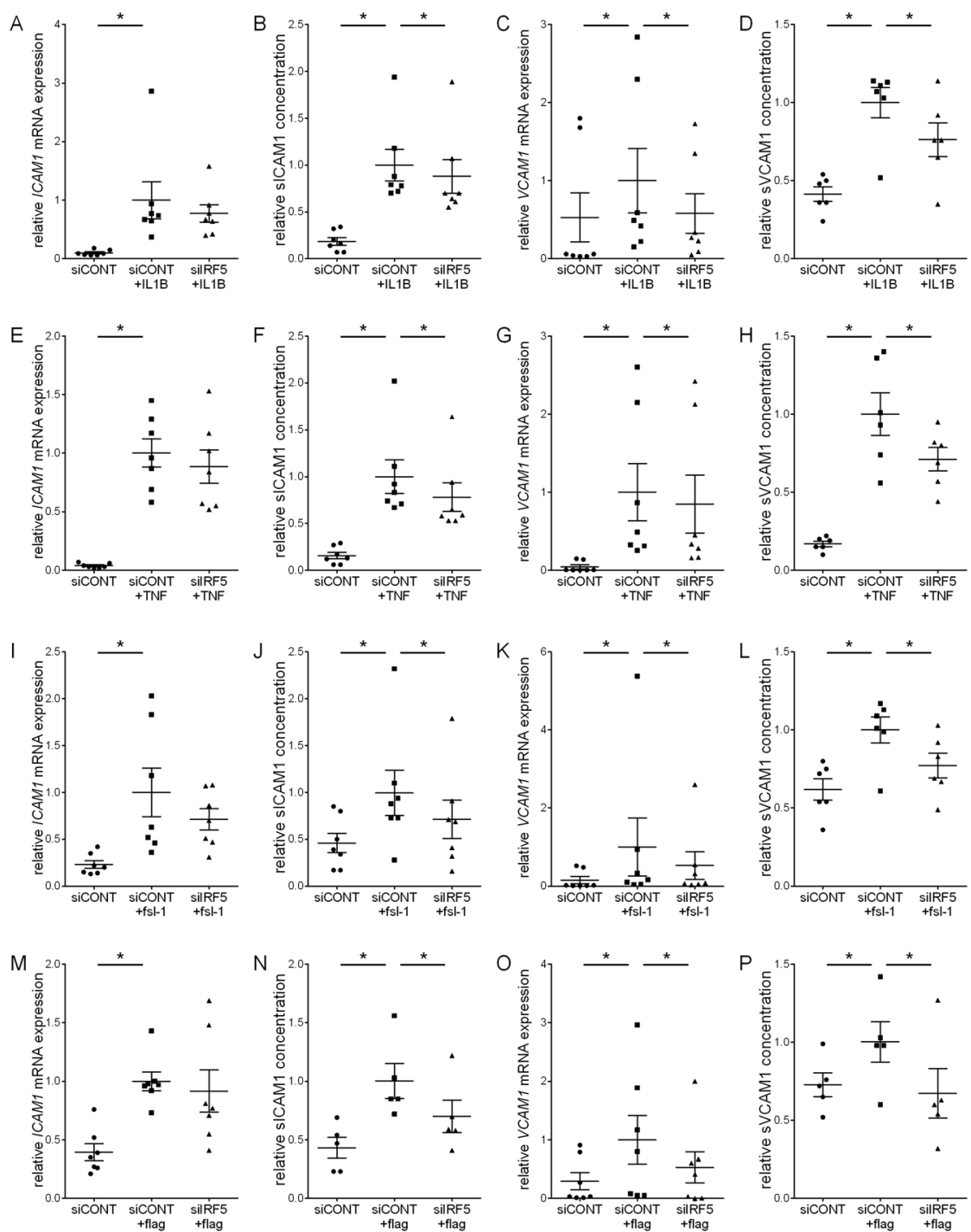

Figure 4 Effect of silRF5 on cell adhesion molecules in primary myometrial cells. Human primary myometrial cells were transfected with $50 \mathrm{nM}$ siCONT or $50 \mathrm{nM}$ silRF5 for $48 \mathrm{~h}$ and then treated with $(\mathrm{A}, \mathrm{B}, \mathrm{C}$ and D) $1 \mathrm{ng} / \mathrm{mL} I L 1 B,(E, F, G$ and H) $10 \mathrm{ng} / \mathrm{mL}$ TNF, (I, J, K and L) $250 \mathrm{ng} / \mathrm{mL}$ fsl-1 or (M, N, O and P) $1 \mu \mathrm{g} / \mathrm{mL}$ flagellin (flag) for an additional $20 \mathrm{~h}$ ( $n=5-7$ patients). (A, C, E, G, I, K, M, O) ICAM1 and VCAM1 mRNA expression was analysed by qRT-PCR. (B, D, F, H, J, L, N and P) The concentration of sICAM1 and SVCAM1 in the incubation medium was assayed by ELISA. For all data, the fold change was calculated relative to IL1B-, TNF-, fsl-1- or flag-treated cells. Individual data points represent 5-7 independent experiments and displayed as mean \pm S.E.M. $* P \leq 0.05$ (repeated measures one-way ANOVA).

be attributed to the infiltration of leukocytes observed in labouring tissues. Leukocytes are a rich source of IL1B and TNF, two acute phase pro-inflammatory cytokines that are also upregulated in myometrium during labour (Young et al. 2002, Tattersall et al. 2008). In our studies, treatment of primary human myometrial cells with IL1B or TNF significantly increased IRF5 mRNA expression. Collectively, this suggests that the increase in IRF5 expression seen in labouring myometrium may be a consequence of the inflammatory response associated with labour.

Inflammation induces a cascade of events that activates the myometrium culminating in preterm labour. Inflammation can originate either locally or systemically and is triggered by infection or by sterile pro-inflammatory insults. Pro-inflammatory cytokines such as TNF and IL1B and bacterial products such as fsl- 1 and flagellin can induce an inflammatory response in myometrium (Rauk \& Chiao 2000, Liang et al. 2008, Lim et al. 2014, 2017a,b, Lappas 2017b). They can induce chemokines

and cellular adhesion molecules, which can stimulate an influx of leukocytes into myometrium. They can also induce uterine contractions by increasing the expression of contraction-associated proteins such as PTGS2 and PTGFR as well as inducing the production of uterotonic prostaglandins such as $\mathrm{PGF}_{2 \alpha}$. IRF5 has emerged as an important pro-inflammatory transcription factor involved in acute and chronic inflammation (Takaoka et al. 2005, Paun et al. 2008, Krausgruber et al. 2010, 2011, Tada et al. 2011, Feng et al. 2012, Hedl \& Abraham 2012, Xu et al. 2012, Ren et al. 2014, Duffau et al. 2015, Weiss et al. 2015, Alzaid et al. 2016, Oriss et al. 2017). Thus, functional studies were then performed to investigate if IRF5 may play a role in regulating pro-inflammatory and pro-labour mediators induced by the pro-inflammatory cytokines IL1B and TNF or bacterial products and TLR ligands fsl- 1 and flagellin.

We found that, for the most part, IRF5 silencing was associated with a blunting of the inflammatory response in myometrial cells suggesting that that IRF5 

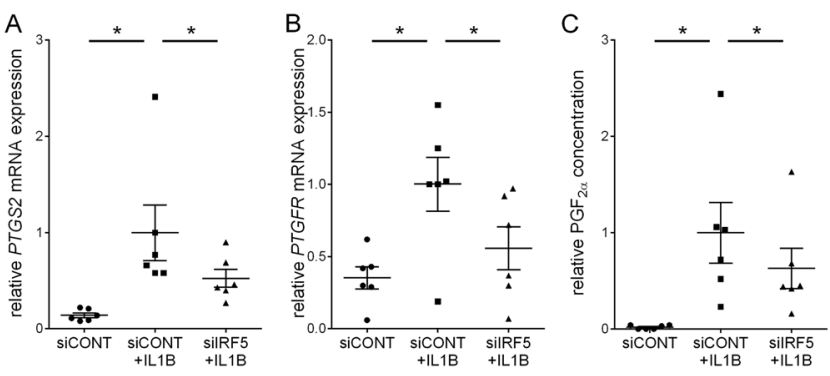

Figure 5 Effect of silRF5 on contraction-associated proteins in primary myometrial cells. Human primary myometrial cells were transfected with $50 \mathrm{nM}$ siCONT or $50 \mathrm{nM}$ silRF5 for $48 \mathrm{~h}$ and then treated with $1 \mathrm{ng} / \mathrm{mL}$ IL1B for an additional $20 \mathrm{~h}$ ( $n=6$ patients). (A and B) PTGS2 and PTGFR mRNA expression was analysed by qRT-PCR. (C) The concentration of $\mathrm{PGF}_{2 \alpha}$ in the incubation medium was assayed by ELISA. For all data, the fold change was calculated relative to IL1B-treated cells. Individual data points represent 6 independent experiments and displayed as mean \pm S.E.M. ${ }^{*} P \leq 0.05$ (repeated measures one-way ANOVA).

plays an important role in cytokine and TLR signalling pathways associated with preterm labour. Specifically, the expression and or secretion of pro-inflammatory cytokines (IL1A, IL6), chemokines (CCL2, CXCL1, CXCL8), adhesion molecules (ICAM1, VCAM1) and contraction-associated proteins (PTGS2, PTGFR, PGF $_{2 \alpha}$ ) was significantly suppressed in silRF5-transfected cells when compared to siCONT-transfected cells. The reduction in mRNA expression or secretion of pro-labour mediators by silRF5 ranged from $20 \%$ to $50 \%$. The biological relevance of this decrease cannot be inferred from these studies as all data were from in vitro siRNA experiments using cells isolated from myometrium. Regardless of this limitation, our in vitro studies suggest that in a setting of increased IRF5 expression, myometrial inflammation is increased. This infers that myometrial IRF5 transcriptionally induces pro-inflammatory and pro-labour mediators in myometrium.

In non-gestational tissues, IRF5 has been shown to regulate inflammation by interacting with the RELA subunit of NF-kB. Specifically, IRF5 forms a protein complex with RELA to drive a sustained induction of the human TNF gene (Krausgruber et al. 2010) while IRF5 genome recruitment to inflammatory genes is aided by RELA (Saliba et al. 2014). Furthermore, IRF5 has also been shown to directly induce the activation of RELA; IRF5 knockdown profoundly decreases RELA pathway activation (Hedl \& Abraham 2012). Numerous studies over the last 20 years have shown that NF-кB plays a central role in regulating pro-inflammatory and pro-labour mediators in human gestational tissues (Lindstrom \& Bennett 2005, Lappas \& Rice 2007). Thus, we hypothesised that IRF5 may also regulate pro-labour mediators in primary myometrial cells through NF- $\mathrm{kB}$. We addressed this by determining the effect of silRF5 on NF-KB RELA transcriptional activity using a luciferase assay. The effect of silRF5 was a significant suppression of NF-KB RELA activation induced by the pro-inflammatory cytokines IL1B and TNF and the bacterial products fsl-1 and flagellin. This suggests that in the absence of IRF5, primary myometrial cells display hypoactive RELA, which would result in decreased transcription of proinflammatory and pro-labour genes. Collectively, these findings suggest that in human myometrium, IRF5 is a mediator of the NF- $\mathrm{kB}$ signalling pathway, corroborating the potential of IRF5 as a therapeutic target for the prevention of preterm labour.

Much research over the last decade has been focussed on the identification of inflammatory molecules that can be targeted to mitigate the inflammatory response associated with preterm labour. In addition to NF- $\mathrm{kB}$, we have identified a number of regulators of inflammation including A20 (Lappas 2017a), Kruppel-like factor 5 (KLF5) (Lappas 2015), sirtuins (SIRTs) (Lappas et al. 2011, Lim et al. 2013b, 2016a, Poljak et al. 2014) and forkhead box O (FOXO) proteins (Lim et al. 2013a). Whether IRF5 may interact with these signalling proteins to regulate pro-labour mediators is not known and an avenue for further research.

In conclusion, we have identified a novel role of IRF5 in regulating the inflammatory response in human myometrium. Specifically, IRF5 expression is increased
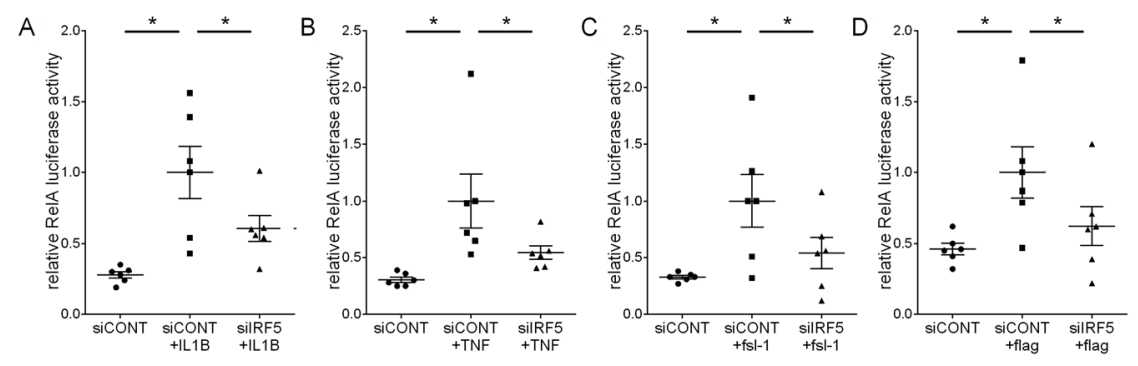

Figure 6 Effect of silRF5 on NF-kB RELA transcriptional activity. Human myometrial cells were transfected with $0.75 \mathrm{ng} \mathrm{NF}-\mathrm{kB}$ RELA reporter construct. After $6 \mathrm{~h}$, cells were transfected with $50 \mathrm{nM}$ siCONT or $50 \mathrm{nM}$ silRF5 for $48 \mathrm{~h}$, then treated with (A) $1 \mathrm{ng} / \mathrm{mL}$ IL1B, (B) $10 \mathrm{ng} / \mathrm{mL} \mathrm{TNF}$, (C) $250 \mathrm{ng} / \mathrm{mL}$ fsl-1 or (D) $1 \mu \mathrm{g} / \mathrm{mL}$ flagellin (flag) for an additional $20 \mathrm{~h}$ ( $n=6$ patients). RELA promoter activity (normalised to Renilla) is expressed as a ratio of luciferase activity of IL1B-, TNF-, fsI-1- or flag-stimulated siCONT transfected cells. Individual data points represent 6 independent experiments and displayed as mean \pm S.E.M. $* P \leq 0.05$ (repeated-measures one-way ANOVA). 
in myometrium with labour and the coincident proinflammatory cytokines IL1B and TNF. Increased IRF5 expression is associated with an exaggerated inflammatory response that is characterised by increased expression of pro-inflammatory cytokines, chemokines, adhesion molecules, contraction-associated proteins and prostaglandins leading to labour. This cascade of events is further amplified by pro-inflammatory cytokines. Further studies are requited in order to elucidate the role of IRF5 in the processes of labour. In particular, it would be of interest to determine the role of IRF5 in foetal membranes as they also play an important role in releasing pro-inflammatory mediators that can contribute to labour (Menon 2016). Furthermore, the relationship between IRF5 and progesterone receptors should be examined given a recent report suggesting a direct correlation between loss of IRF5 expression and progesterone receptor expression (Pimenta et al. 2015). This is of importance as progesterone receptors mediate the actions of progesterone and thus play an important role in controlling myometrial contractility and the parturition process (Mesiano et al. 2010).

\section{Declaration of interest}

The authors declare that there is no conflict of interest that could be perceived as prejudicing the impartiality of the research reported.

\section{Funding}

Associate Professor Martha Lappas is supported by a Career Development Fellowship from the National Health and Medical Research Council (NHMRC; grant no. 1047025) and a Research Fellowship from The University of Melbourne. Funding for this study was provided by the NHMRC (grant no. 1058786), Norman Beischer Medical Research Foundation, the University of Melbourne and the Mercy Research Foundation.

\section{Acknowledgements}

The following are gratefully acknowledged: the clinical research midwives Genevieve Christophers, Gabrielle Pell, and Rachel Murdoch for sample collection and the Obstetrics and Midwifery staff of the Mercy Hospital for Women for their cooperation.

\section{References}

Alzaid F, Lagadec F, Albuquerque M, Ballaire R, Orliaguet L, Hainault I, Blugeon C, Lemoine S, Lehuen A, Saliba DG et al. 2016 IRF5 governs liver macrophage activation that promotes hepatic fibrosis in mice and humans. JCI Insight 1 e88689. (https://doi.org/10.1172/jci.insight.88689)

Barton GM \& Medzhitov R 2003 Toll-like receptor signaling pathways. Science 300 1524-1525. (https://doi.org/10.1126/science.1085536)

Beck S, Wojdyla D, Say L, Betran AP, Merialdi M, Requejo JH, Rubens C, Menon R \& Van Look PF 2010 The worldwide incidence of preterm birth: a systematic review of maternal mortality and morbidity. Bulletin of the World Health Organization 88 31-38. (https://doi.org/10.2471/ BLT.08.062554)

Bollapragada S, Youssef R, Jordan F, Greer I, Norman J \& Nelson S 2009 Term labor is associated with a core inflammatory response in human fetal membranes, myometrium, and cervix. American Journal of Obstetrics and Gynecology 200 e101-e111. (https://doi.org/10.1016/j.ajog.2008.08.032)

Chaemsaithong P, Madan I, Romero R, Than NG, Tarca AL, Draghici S, Bhatti G, Mazor M, Kim CJ, Hassan SS et al. 2013 Characterization of the myometrial transcriptome in women with an arrest of dilatation during labor. Journal of Perinatal Medicine 41 665-681. (https://doi. org/10.1515/jpm-2013-0086)

Christiaens I, Zaragoza DB, Guilbert L, Robertson SA, Mitchell BF \& Olson DM 2008 Inflammatory processes in preterm and term parturition. Journal of Reproductive Immunology 79 50-57. (https://doi. org/10.1016/j.jri.2008.04.002)

Duffau P, Menn-Josephy H, Cuda CM, Dominguez S, Aprahamian TR, Watkins AA, Yasuda K, Monach P, Lafyatis R, Rice LM et al. 2015 Interferon regulatory factor 5 promotes inflammatory arthritis. Arthritis and Rheumatology 67 3146-3157. (https://doi.org/10.1002/art.39321)

Feng D, Yang L, Bi X, Stone RC, Patel P \& Barnes BJ 2012 Protection of Irf5deficient mice from pristane-induced lupus involves altered cytokine production and class switching. European Journal of Immunology 42 1477-1487. (https://doi.org/10.1002/eji.201141642)

Gathungu G, Zhang CK, Zhang W \& Cho JH 2012 A two-marker haplotype in the IRF5 gene is associated with inflammatory bowel disease in a North American cohort. Genes and Immunity 13 351-355. (https://doi. org/10.1038/gene.2011.90)

Goldenberg RL, Culhane JF, lams JD \& Romero R 2008 Epidemiology and causes of preterm birth. Lancet 371 75-84. (https://doi.org/10.1016/ S0140-6736(08)60074-4)

Hedl M \& Abraham C 2012 IRF5 risk polymorphisms contribute to interindividual variance in pattern recognition receptor-mediated cytokine secretion in human monocyte-derived cells. Journal of Immunology 188 5348-5356. (https://doi.org/10.4049/jimmunol.1103319)

Honda K \& Taniguchi T 2006 IRFs: master regulators of signalling by Toll-like receptors and cytosolic pattern-recognition receptors. Nature Reviews Immunology 6 644-658. (https://doi.org/10.1038/nri1900)

Illanes SE, Perez-Sepulveda A, Rice GE \& Mitchell MD 2014 Preterm labour: association between labour physiology, tocolysis and prevention. Expert Opinion on Investigational Drugs 23 759-771. (https://doi.org/10 $.1517 / 13543784.2014 .905541)$

Krausgruber T, Saliba D, Ryzhakov G, Lanfrancotti A, Blazek K \& Udalova IA 2010 IRF5 is required for late-phase TNF secretion by human dendritic cells. Blood 115 4421-4430. (https://doi.org/10.1182/ blood-2010-01-263020)

Krausgruber T, Blazek K, Smallie T, Alzabin S, Lockstone H, Sahgal N, Hussell T, Feldmann M \& Udalova IA 2011 IRF5 promotes inflammatory macrophage polarization and TH1-TH17 responses. Nature Immunology 12 231-238. (https://doi.org/10.1038/ni.1990)

Lappas M 2015 KLF5 regulates infection- and inflammation-induced prolabour mediators in human myometrium. Reproduction 149 413-424. (https://doi.org/10.1530/REP-14-0597)

Lappas M 2017a A20, an essential component of the ubiquitin-editing protein complex, is a negative regulator of inflammation in human myometrium and foetal membranes. Molecular Human Reproduction 23 628-645. (https://doi.org/10.1093/molehr/gax041)

Lappas M 2017b The IL-1beta signalling pathway and its role in regulating pro-inflammatory and pro-labour mediators in human primary myometrial cells. Reproductive Biology 17 333-340. (https://doi. org/10.1016/j.repbio.2017.09.006)

Lappas M 2018 Runt-related transcription factor 1 (RUNX1) deficiency attenuates inflammation-induced pro-inflammatory and pro-labour mediators in myometrium. Molecular and Cellular Endocrinology Epub. (https://doi.org/10.1016/j.mce.2018.01.003)

Lappas M \& Rice GE 2007 The role and regulation of the nuclear factor kappa B signalling pathway in human labour. Placenta 28 543-556. (https://doi.org/10.1016/j.placenta.2006.05.011)

Lappas M, Mitton A, Lim R, Barker G, Riley C \& Permezel M 2011 SIRT1 is a novel regulator of key pathways of human labor. Biology of Reproduction 84 167-178. (https://doi.org/10.1095/biolreprod.110.086983)

Lee YH, Bae SC, Choi SJ, Ji JD \& Song GG 2013 Associations between interferon regulatory factor 5 polymorphisms and rheumatoid arthritis: 
a meta-analysis. Molecular Biology Reports 40 1791-1799. (https://doi. org/10.1007/s11033-012-2233-4)

Liang Z, Sooranna SR, Engineer N, Tattersall M, Khanjani S, Bennett PR, Myatt L \& Johnson MR 2008 Prostaglandin F2-alpha receptor regulation in human uterine myocytes. Molecular Human Reproduction $\mathbf{1 4}$ 215-223. (https://doi.org/10.1093/molehr/gan008)

Lim R, Barker G \& Lappas M 2013a A novel role for FOXO3 in human labor: increased expression in laboring myometrium, and regulation of proinflammatory and prolabor mediators in pregnant human myometrial cells. Biology of Reproduction 88 156. (https://doi.org/10.1095/ biolreprod.113.108126)

Lim R, Barker G \& Lappas M 2013b SIRT6 is decreased with preterm labor and regulates key terminal effector pathways of human labor in fetal membranes. Biology of Reproduction 88 17. (https://doi.org/10.1095/ biolreprod.112.105163)

Lim R, Barker G \& Lappas M 2014 The TLR2 ligand FSL-1 and the TLR5 ligand Flagellin mediate pro-inflammatory and pro-labour response via MyD88/TRAF6/NF-kappaB-dependent signalling. American Journal of Reproductive Immunology 71 401-417. (https://doi.org/10.1111/ aji.12229)

Lim R, Barker G \& Lappas M 2015 Activation of AMPK in human fetal membranes alleviates infection-induced expression of pro-inflammatory and pro-labour mediators. Placenta 36 454-462. (https://doi. org/10.1016/j.placenta.2015.01.007)

Lim R, Barker G, Menon R \& Lappas M 2016a A novel role for SIRT3 in regulating mediators involved in the terminal pathways of human labor and delivery. Biology of Reproduction 95 95. (https://doi.org/10.1095/ biolreprod.116.142372)

Lim R, Tran HT, Liong S, Barker G \& Lappas M 2016b The transcription factor interferon regulatory factor-1 (IRF1) plays a key role in the terminal effector pathways of human preterm labor. Biology of Reproduction 94 32. (https://doi.org/10.1095/biolreprod.115.134726)

Lim R, Barker G \& Lappas M 2017a TLR2, TLR3 and TLR5 regulation of proinflammatory and pro-labour mediators in human primary myometrial cells. Journal of Reproductive Immunology 122 28-36. (https://doi. org/10.1016/j.jri.2017.08.004)

Lim R, Barker G \& Lappas M 2017b TRADD, TRAF2, RIP1 and TAK1 are required for TNF-alpha-induced pro-labour mediators in human primary myometrial cells. American Journal of Reproductive Immunology $\mathbf{7 8}$ e12664. (https://doi.org/10.1111/aji.12664)

Lindstrom TM \& Bennett PR 2005 The role of nuclear factor kappa B in human labour. Reproduction 130 569-581. (https://doi.org/10.1530/ rep.1.00197)

Liu L, Johnson HL, Cousens S, Perin J, Scott S, Lawn JE, Rudan I, Campbell H, Cibulskis R, Li M et al. 2012 Global, regional, and national causes of child mortality: an updated systematic analysis for 2010 with time trends since 2000. Lancet 379 2151-2161. (https://doi.org/10.1016/ S0140-6736(12)60560-1)

Menon R 2016 Human fetal membranes at term: dead tissue or signalers of parturition? Placenta 44 1-5. (https://doi.org/10.1016/j. placenta.2016.05.013)

Mesiano S, Wang Y \& Norwitz ER 2010 Progesterone receptors in the human pregnancy uterus: do they hold the key to birth timing? Reproductive Sciences 18 6-19. (https://doi.org/10.1177/1933719110382922)

Mitchell BF, Aguilar HN, Mosher A, Wood S \& Slater DM 2013 The uterine myocyte as a target for prevention of preterm birth. Facts, Views and Vision in ObGyn $\mathbf{5}$ 72-81.

Mittal P, Romero R, Tarca AL, Gonzalez J, Draghici S, Xu Y, Dong Z, NhanChang C-L, Chaiworapongsa T, Lye S et al. 2010 Characterization of the myometrial transcriptome and biological pathways of spontaneous human labor at term. Journal of Perinatal Medicine, 38 617-643. (https:// doi.org/10.1515/JPM.2010.097)

Mwaniki MK, Atieno M, Lawn JE \& Newton CR 2012 Long-term neurodevelopmental outcomes after intrauterine and neonatal insults: a systematic review. Lancet 379 445-452. (https://doi.org/10.1016/S01406736(11)61577-8)

Nadeau-Vallee M, Obari D, Quiniou C, Lubell WD, Olson DM, Girard S \& Chemtob S 2016 A critical role of interleukin-1 in preterm labor. Cytokine and Growth Factor Reviews 28 37-51. (https://doi. org/10.1016/j.cytogfr.2015.11.001)

Olson DM 2003 The role of prostaglandins in the initiation of parturition. Best Practice and Research: Clinical Obstetrics and Gynaecology 17 717-730. (https://doi.org/10.1016/S1521-6934(03)00069-5)
Oriss TB, Raundhal M, Morse C, Huff RE, Das S, Hannum R, Gauthier MC, Scholl KL, Chakraborty K, Nouraie SM et al. 2017 IRF5 distinguishes severe asthma in humans and drives Th1 phenotype and airway hyperreactivity in mice. JCl Insight 2 16. (https://doi.org/10.1172/jci. insight.91019)

Osman I, Young A, Ledingham MA, Thomson AJ, Jordan F, Greer IA \& Norman JE 2003 Leukocyte density and pro-inflammatory cytokine expression in human fetal membranes, decidua, cervix and myometrium before and during labour at term. Molecular Human Reproduction 9 41-45. (https://doi.org/10.1093/molehr/gag001)

Paun A, Reinert JT, Jiang Z, Medin C, Balkhi MY, Fitzgerald KA \& Pitha PM 2008 Functional characterization of murine interferon regulatory factor 5 (IRF-5) and its role in the innate antiviral response. Journal of Biological Chemistry 283 14295-14308. (https://doi.org/10.1074/jbc. M800501200)

Petrou S, Eddama O \& Mangham L 2011 A structured review of the recent literature on the economic consequences of preterm birth. Archives of Disease in Childhood-Fetal and Neonatal Edition 96 F225-F232. (https:// doi.org/10.1136/adc.2009.161117)

Pimenta EM, De S, Weiss R, Feng D, Hall K, Kilic S, Bhanot G, Ganesan S, Ran S \& Barnes BJ 2015 IRF5 is a novel regulator of CXCL13 expression in breast cancer that regulates CXCR5(+) B- and T-cell trafficking to tumor-conditioned media. Immunology and Cell Biology 93 486-499. (https://doi.org/10.1038/icb.2014.110)

Poljak M, Lim R, Barker G \& Lappas M 2014 Class I to III histone deacetylases differentially regulate inflammation-induced matrix metalloproteinase 9 expression in primary amnion cells. Reproductive Sciences 21 804-813. (https://doi.org/10.1177/1933719113518990)

Rauk PN \& Chiao JP 2000 Interleukin-1 stimulates human uterine prostaglandin production through induction of cyclooxygenase-2 expression. American Journal of Reproductive Immunology 43 152-159. (https://doi.org/10.1111/j.8755-8920.2000.430304.x)

Rauk PN, Friebe-Hoffmann U, Winebrenner LD \& Chiao JP 2001 Interleukin-6 up-regulates the oxytocin receptor in cultured uterine smooth muscle cells. American Journal of Reproductive Immunology 45 148-153. (https://doi.org/10.1111/j.8755-8920.2001.450305.x)

Ren J, Chen X \& Chen ZJ 2014 IKKbeta is an IRF5 kinase that instigates inflammation. PNAS 111 17438-17443. (https://doi.org/10.1073/ pnas.1418516111)

Romero R, Espinoza J, Goncalves LF, Kusanovic JP, Friel LA \& Nien JK 2006 Inflammation in preterm and term labour and delivery. Seminars in Fetal and Neonatal Medicine 11 317-326. (https://doi.org/10.1016/j. siny.2006.05.001)

Rubens CE, Sadovsky Y, Muglia L, Gravett MG, Lackritz E \& Gravett C 2014 Prevention of preterm birth: harnessing science to address the global epidemic. Science Translational Medicine 6 262sr265.

Saigal S \& Doyle LW 2008 An overview of mortality and sequelae of preterm birth from infancy to adulthood. Lancet 371 261-269. (https:// doi.org/10.1016/S0140-6736(08)60136-1)

Saliba DG, Heger A, Eames HL, Oikonomopoulos S, Teixeira A, Blazek K, Androulidaki A, Wong D, Goh FG, Weiss M et al. 2014 IRF5:RelA interaction targets inflammatory genes in macrophages. Cell Reports $\mathbf{8}$ 1308-1317. (https://doi.org/10.1016/j.celrep.2014.07.034)

Salloum R \& Niewold TB 2011 Interferon regulatory factors in human lupus pathogenesis. Translational Research 157 326-331. (https://doi. org/10.1016/j.trsl.2011.01.006)

Shynlova O, Lee YH, Srikhajon K \& Lye SJ 2013 Physiologic uterine inflammation and labor onset: integration of endocrine and mechanical signals. Reproductive Sciences 20 154-167. (https://doi. org/10.1177/1933719112446084)

Singh N, Herbert B, Sooranna GR, Orsi NM, Edey L, Dasgupta T, Sooranna SR, Yellon SM \& Johnson MR 2017 Is myometrial inflammation a cause or a consequence of term human labour? Journal of Endocrinology 235 69-83. (https://doi.org/10.1530/JOE-17-0318)

Sivarajasingam SP, Imami N \& Johnson MR 2016 Myometrial cytokines and their role in the onset of labour. Journal of Endocrinology 231 R101-R119. (https://doi.org/10.1530/JOE-16-0157)

Swindell WR, Johnston A \& Gudjonsson JE 2010 Transcriptional profiles of leukocyte populations provide a tool for interpreting gene expression patterns associated with high fat diet in mice. PLoS ONE 5 e11861. (https://doi.org/10.1371/journal.pone.0011861)

Tada Y, Kondo S, Aoki S, Koarada S, Inoue H, Suematsu R, Ohta A, Mak TW \& Nagasawa K 2011 Interferon regulatory factor 5 is critical for 
the development of lupus in MRL/lpr mice. Arthritis and Rheumatology 63 738-748. (https://doi.org/10.1002/art.30183)

Takaoka A, Yanai H, Kondo S, Duncan G, Negishi H, Mizutani T, Kano S, Honda K, Ohba Y, Mak TW et al. 2005 Integral role of IRF-5 in the gene induction programme activated by Toll-like receptors. Nature $\mathbf{4 3 4}$ 243-249. (https://doi.org/10.1038/nature03308)

Tattersall M, Engineer N, Khanjani S, Sooranna SR, Roberts VH, Grigsby PL, Liang Z, Myatt L \& Johnson MR 2008 Pro-labour myometrial gene expression: are preterm labour and term labour the same? Reproduction 135 569-579. (https://doi.org/10.1530/REP-07-0461)

van Vliet EO, Boormans EM, de Lange TS, Mol BW \& Oudijk MA 2014 Preterm labor: current pharmacotherapy options for tocolysis. Expert Opinion on Pharmacotherapy 15 787-797. (https://doi.org/10.1517/14 656566.2014.889684)

Wang C, Rose-Zerilli MJ, Koppelman GH, Sandling JK, Holloway JW, Postma DS, Holgate ST, Bours V, Syvanen AC \& Dideberg V 2012 Evidence of association between interferon regulatory factor 5 gene polymorphisms and asthma. Gene 504 220-225. (https://doi. org/10.1016/j.gene.2012.05.021)

Weiner CP, Mason CW, Dong Y, Buhimschi IA, Swaan PW \& Buhimschi CS 2010 Human effector/initiator gene sets that regulate myometrial contractility during term and preterm labor. American Journal of Obstetrics and Gynecology 202 e471-e420. (https://doi.org/10.1016/j. ajog.2010.02.034)

Weiss M, Blazek K, Byrne AJ, Perocheau DP \& Udalova IA 2013 IRF5 is a specific marker of inflammatory macrophages in vivo. Mediators of Inflammation 2013 9. (https://doi.org/10.1155/2013/245804)

Weiss M, Byrne AJ, Blazek K, Saliba DG, Pease JE, Perocheau D, Feldmann M \& Udalova IA 2015 IRF5 controls both acute and chronic inflammation. PNAS 112 11001-11006. (https://doi.org/10.1073/ pnas.1506254112)
Xu Y, Lee PY, Li Y, Liu C, Zhuang H, Han S, Nacionales DC, Weinstein J, Mathews CE, Moldawer LL et al. 2012 Pleiotropic interferon-dependent and -independent effects of IRF5 on the pathogenesis of experimental lupus. Journal of Immunology 188 4113-4121. (https://doi.org/10.4049/ jimmunol.1103113)

Young A, Thomson AJ, Ledingham M, Jordan F, Greer IA \& Norman JE 2002 Immunolocalization of proinflammatory cytokines in myometrium, cervix, and fetal membranes during human parturition at term. Biology of Reproduction 66 445-449. (https://doi.org/10.1095/biolreprod66.2.445)

Yuan M, Jordan F, Mc IBInnes, Harnett MM \& Norman JE 2009 Leukocytes are primed in peripheral blood for activation during term and preterm labour. Molecular Human Reproduction 15 713-724. (https://doi. org/10.1093/molehr/gap054)

Zhao GN, Jiang DS \& Li H 2015 Interferon regulatory factors: at the crossroads of immunity, metabolism, and disease. Biochimica et Biophysica Acta 1852 365-378. (https://doi.org/10.1016/j.bbadis.2014.04.030)

Zhao WJ, Yue XY, Liu K, Zheng JF, Huang RD, Zou J, Riemekasten G, Petersen F \& Yu XH 2017 The status of pulmonary fibrosis in systemic sclerosis is associated with IRF5, STAT4, IRAK1, and CTGF polymorphisms. Rheumatology International 37 1303-1310. (https://doi. org/10.1007/s00296-017-3722-5)

Received 12 March 2018

First decision 18 April 2018

Revised manuscript received 5 June 2018

Accepted 12 June 2018 